\title{
Credit without banks: the Amsterdam water bailiff's ledger of I 856
}

\author{
DAAN VERWAAIJ and CHRISTIAAN VAN BOCHOVE \\ Radboud University
}

\begin{abstract}
Before banks rose to dominate credit markets, ordinary people raised credit themselves or through alternative intermediaries. However, obtaining a comprehensive overview of the size and functioning of the non-bank segments within the credit market has been a great challenge for historians. Notarial deeds are widely available, but typically shed light on the borrowing of relatively well-to-do members of society. Probate inventories and insolvency records do provide insight into the modest loans of ordinary people, but only haphazardly and not for the overall stock of loans. This article exploits an exogenous shock, the Discipline Act introduced in the Netherlands in 1856 , which forced lenders to record all unredeemed loans they had provided to a particular group of borrowers: seafarers. The c.I 4 , Ooo loans that were recorded, in combination with several additional sources, provide a unique insight into the overall size, composition and functioning of a particular segment of the non-bank credit market.
\end{abstract}

Keywords: non-bank credit, loans, seafarers, Amsterdam, nineteenth century

JEL classification: $\mathrm{N}_{24}, \mathrm{~N}_{34}, \mathrm{~N}_{74}, \mathrm{~N}_{84}$

Credit fulfils an important role in society as it allows people to use future revenues to purchase goods and services in the present. Banks play a major role in bringing together demand and supply on present-day credit markets, but prior to World War II they only served a small, elite clientele. This did not mean, though, that credit markets and financial intermediation for ordinary people were absent or underdeveloped. In the footsteps of Muldrew, for instance, it has now been well established that people could accomplish quite a lot themselves (Muldrew I998; Finn 2003; Ogilvie, Kükpker and Maegraith 20I2; Fontaine 20I4; Van Bochove and Kole 20I4). Inspired by the work of Hoffman, Postel-Vinay and Rosenthal, it has likewise

C. van Bochove (corresponding author), Department of History, Radboud University Nijmegen, P.O. Box 9I03, 6500 HD Nijmegen (Netherlands); email: C.vanBochove@let.ru.nl. D. Verwaaij, Department of History, Radboud University Nijmegen. This article is partially based on the BA thesis of one of the authors. We are grateful to two anonymous referees for helpful comments and suggestions. We would also like to thank Harm Kaal and Marja Goud for their help with getting access to some primary and secondary sources. The usual disclaimer applies. 
become clear that alternative intermediaries were available when necessary (Hoffman, Postel-Vinay and Rosenthal 2000; Levy 20I2; Van Bochove and Van Velzen 20I4). However, obtaining a comprehensive overview of the size and functioning of the non-bank segments of the credit market has been a great challenge for historians. They have therefore often turned to notarial archives as these have frequently been preserved fairly completely, but processing notarial deeds is very labour intensive. ${ }^{1}$ A further disadvantage of notarial deeds is that they only provide information about new loans granted to relatively well-to-do members of society. Probate inventories and insolvency records, on the other hand, do provide insight into the modest loans of ordinary people, but only haphazardly and not for the overall stock of loans (Willems 2009; Van Bochove and Kole 20I4). It consequently remains unclear how large the non-bank credit markets for ordinary people actually were.

This article exploits an exogenous shock, a law introduced in the Netherlands in I 856 (the Discipline Act or Tuchtwet), which forced lenders to record all unredeemed loans they had provided to a particular group of borrowers: seafarers. ${ }^{2}$ Seafarers were an important group around the globe: they were numerous ${ }^{3}$ they provided a vital contribution to trade and hence the economy; and as wages were only paid after a journey they were always in need of credit. The Discipline Act forbade lenders from collecting the wages of seafarers as redemption payments, as borrowers had until then allowed them to do. The Act also stipulated that all unredeemed loans had to be registered in a government ledger. As unregistered loans would become void, this incentivised lenders to record all unredeemed loans. This article uses the ledger from the city of Amsterdam, which at around this time was one of the three largest ports in Europe (Aerts 2006, p. 28), ${ }^{4}$ to provide a unique snapshot of the

1 Hoffman, Postel-Vinay and Rosenthal 2000 could only carry out their groundbreaking work because they were able to rely on registers that summarised their notarial deeds. This did not apply to other parts of Europe, so that comprehensive work there had to rely on sample years. See Gelderblom, Hup and Jonker 20I 8; Lorenzini 2018.

2 'Wet van den 7den mei I 856, houdende bepalingen omtrent de huishouding en tucht op de koopvaardijschepen' (Staatsblad van het Koningrijk der Nederlanden 32); Amsterdam City Archive, Archief van de Waterschout (entry no. 38) (henceforth ACA, Waterschout), inv. no. I78.

3 Whilst the available sources show that an average of 2,I53 ships left the Amsterdam port each year between I 840 and I856, they do not provide a breakdown of these departures by destination. However, with manning ratios of 6,20 and 40 on destinations within Europa, Africa and the West Indies, and the East Indies respectively, this most likely meant that I 5,000 to 20,000 seafarers departed annually from Amsterdam. This is quite a considerable number given that Amsterdam was home to about 220,000 people at the time. See Handelingen der Staten-Generaal, I84I-2, pp. 626, 63I; I842-3, pp. I585, I590; I843-4, pp. 7I4, 7I9; I844-5, pp. I245, I250; I845-6, pp. 69I, 696; Algemeen Handelsblad, I3 August I847; Statistisch Jaarboek der Gemeente Amsterdam II, p. I52; Van Leeuwen and Oeppen I993, p. 87; Van Lottum 2007, p. 2 I2.

4 The Amsterdam ledger seems to be the only one that has survived. For the northern provinces (i.e. Friesland, Groningen, Drenthe and Overijssel) this is based on data kindly provided by Dr Jur Leinenga (p.c.). For the western provinces (i.e. Noord-Holland, Zuid-Holland and Zeeland) this is based on the online archival inventories. 
overall size and composition of a particular segment of the non-bank credit market. ${ }^{5}$ Using address books, seafarers' original IOUs, newspaper advertisements, petitions, minutes of parliamentary meetings and the population register, this article also provides deeper insight into the functioning of this part of the credit market. The combination of all sources, moreover, makes it possible to estimate the total number of new loans provided annually during the period i 839-52.

These sources demonstrate that lenders provided 2,000 to 4,000 new loans each year between I 839 and I 852 . In July I856, at the time that the 443-page ledger was assembled, a total of 13,708 small and medium-sized loans were fully or partially unredeemed. Together they amounted to a sum of around 4I6,000 guilders, or almost 2 I,Ooo monthly wages of a sailor. ${ }^{6}$ A substantial part of this was provided by a relatively small group of specialised shopkeepers and boarding-house keepers, the infamous crimps of the sailor-town literature. While their vital role as providers of credit has been recognised in prior literature, little is actually known about their credit operations (Hugill 1967; Bruijn 1977, I978; Fingard 1978, I980; Dixon 1984; Muldrew I998; Finn 2003; Gamber 2007; Van Rossum 2008; Landheer 2013; Fontaine 2014; Van Bochove 20 I4; Milne 20I6; Morris and Cozens 20I7; Hell 20I7). The literature that focused on the shopping landscape and the products that shopkeepers sold also paid little attention to the credit that shopkeepers provided in the process of selling their goods (Lesger 20I3; Furnée and Lesger 2014). Moreover, the literature that focused on consumer credit primarily looked at the innovations introduced during the nineteenth and twentieth centuries (such as instalment credit, check trading and the credit card) rather than on the use of shop credit. Those publications that did focus on shop credit did not have data with a sufficient amount of detail as compared to what is available for mid-nineteenth-century Amsterdam. ${ }^{7}$ This article thus contributes not only to the literature on non-bank credit markets, but also to the literature on shopkeepers and boarding-house keepers and their role as a source of credit.

The article proceeds as follows. Section II introduces the credit market for seafarers and the Discipline Act. It also discusses the ledger in which all unredeemed loans were registered. Section III then analyses the unredeemed loans recorded in this ledger. Section IV zooms in on the lenders and Section $\mathrm{v}$ focuses on one individual, Cas

5 This article hence also contributes to the literature on Amsterdam's financial market, which primarily focuses on the world of high finance and the credit provided by banks to their small, elite clientele. See, for instance, Jonker I996.

6 Muster rolls from the years I 836-8 (Van Bochove, Van Lottum and Mourits 20I6) and I84I-4, I 852 (ACA, Waterschout, inv. no. I 52) demonstrate that during the period prior to the Discipline Act the default wage for a sailor was 20 guilders.

7 For consumer credit, see Olney I99 I; Gelpi and Julien-Labruyère 2000; O'Connell 2009; Albert 20 I2; Easterly 2008, 2009. For (the continued use of) shop credit, see Johnson I985; Kent I994; Olney I998; Willems 2009; Laferté, Avanza, Fontaine and Penissat 20I0; Logemann and Spiekermann 20I0; Logemann 2012; Lluch 2016. 
Spijker: the most important lender found in the ledger. Section vi extrapolates from Spijker to the overall market and Section VII summarises and concludes.

During the two decades prior to I 856 some I, 900 to 2,300 ships departed from the port of Amsterdam each year. ${ }^{8}$ Many of the seafarers who sailed on these ships depended on credit to pay for board and lodging, to purchase shipping gear, and to buy goods for personal and household use as well as for private trade. Already during the early modern period seafarers in the Netherlands had discovered that they could use their future wages for obtaining that credit. By allowing the party responsible for the monitoring of their wage payments to withhold specified sums of money and to use these to make redemption payments to their lenders (and to record those on the IOUs), seafarers managed to effectively secure their loans. A municipal official who was present when seafarers were mustered and discharged, the socalled water bailiff (waterschout), was responsible for performing this task. The archival sources demonstrate that this official supported a lively credit market for seafarers (Van Bochove 20I4; Van Bochove, Van Lottum and Mourits 20I6; Blakemore 20I7). ${ }^{9}$

The Discipline Act changed all this, however, as it prohibited the water bailiff henceforth from serving the interests of borrowers and lenders. The Act was introduced by the Dutch parliament in I856 to address an issue unrelated to credit markets: the increasing desertion of seafarers on Dutch ships, who were lured away in foreign ports by wages that were driven up by the gold rushes in California and Australia. ${ }^{10}$ To give captains and shipping companies more instruments to combat desertion and counteract its costs, lawmakers deemed it necessary to abolish the common practice of making wage payments to lenders (article 2I). By no longer making these redemption payments, direct wage payments to seafarers would increase and this would enable captains and shipping companies to recoup a larger part of the costs of hiring more expensive crews abroad. Although the draft Act was intended to cover all loans, major lenders from Amsterdam and Rotterdam - through the common practice of petitioning parliament - as well as members of parliament insisted that changing the law without transitional arrangements would be unreasonable. The Minister of Justice agreed with them and the final Act therefore exempted as yet unredeemed loans. This only applied, however, when lenders registered these loans before a set date in a ledger with the local water bailiff. This not only provided

8 Van Bochove 20I4, n. 39; Algemeen Handelsblad, I 3 August I 847.

${ }^{9}$ During the seventeenth and eighteenth centuries the cashiers of the Dutch East India Company carried out this task for those sailing to Asia. See Van Bochove and Van Velzen 2014.

10 Those who lobbied in favour of the Discipline Act did not intend to take over lending from shopkeepers and boarding-house keepers. Van Bochove 20 I 4 showed, moreover, that even after the introduction of the Discipline Act, lending to seafarers continued to be dominated by these traditional lenders. 
a good solution to the antedating of loans, but as unregistered loans became void it also ensured that lenders had good reason to use the ledger (Bik and Roos I995; Schuman I995). ${ }^{11}$

The Discipline Act prescribed that lenders had to present their unredeemed IOUs to the water bailiffs during the month of July i 856. In Amsterdam, the water bailiff's office was located in the Schreierstoren in the middle of one of the seafarers' quarters and it was open for registering IOUs six days per week. On one occasion, clerks even worked overtime on a Sunday; presumably because the company of H. Lond, one of the largest lenders in town, had delivered its I,3 I4 unredeemed IOUs the day before and they did not want to start the new week with such a backlog. For every single IOU the clerks recorded basic information: the date on which it was entered into the ledger, the names of lender and borrower, the date of the (last repayment on the) loan and the unredeemed amount. Thus, the ledger did not contain the original IOUs, did not include information on borrowers' nationalities and destinations, and did not make a distinction between loans on which repayments had and had not been made. The clerks typically entered lenders' IOUs consecutively during a single day, but there existed two exceptions to this. First, a few lenders appeared on more than one day, but the first of their appearances was numerically always most important by far. This suggests that lenders typically managed their accounts well, but that a few IOUs were sometimes misplaced (but recovered just in time to be registered in the ledger). Second, in a few instances the loans recorded by one lender were interspersed with some loans of another lender. This suggests that lenders either presented loans on behalf of others or that they had purchased such loans on the secondary market. ${ }^{12}$

The wide variety of lenders and the large number of loans they presented for registration in the ledger confirm that the incentive to register was indeed strong. The ledger not only contains large lenders, but also many small and medium-sized ones who made the effort to register just one $(n=74)$ or only a handful of IOUs rather than write them off. The ledger likewise contains active lenders (i.e. I I 9 persons who presented IOUs 'dated' I856) as well as inactive ones (i.e. 47 persons with IOUs 'dated' i 85 I or earlier). The background of lenders, moreover, was diverse: the ledger not only included shopkeepers and boarding-house keepers (see below), but also three ship's captains, seven shipping companies, an unmarried woman and 3 I widows.

11 For the House of Representatives, see Handelingen der Tweede Kamer, I 854 (29 November), I 855 (8, 2 I May; I6, I8-I9 June; 20 September; 3 October; 7 November; I, I 2 December) and I856 (5, 7, I 4-I 5 , 2 I February; 3, 5, 7 March; 3, 8, I I-I 5 April; I9 September). For the Senate, see Handelingen der Eerste Kamer, I856 (29 April; 2, 6 May). 'Wet van den 7den mei I 856, houdende bepalingen omtrent de huishouding en tucht op de koopvaardijschepen' (Staatsblad van het Koningrijk der Nederlanden 32); 'Circulaire van den Minister van Justitie van den 3 Isten Mei I 856, no. I 20, nopens de rigtige uitvoering der wet, houdende bepalingen omtrent de huishouding en tucht op de koopvaardijschepen' (Bijvoegsel tot het Staatsblad van het Koningrijk der Nederlanden I22). See also the brochure (Van Hasselt I 856) and dissertation (Van der Leeuw I 857) that were published about the Discipline Act.

12 For the transfer of an IOU, see ACA, Waterschout, inv. no. I7I (scan 329). 
The water bailiff's ledger is thus a rich source, but before proceeding to the analysis it needs to be considered whether lenders withheld credit and pushed for repayments once lawmakers started debating the Discipline Act. There are several reasons for believing this was not the case. Advertisements and reports in newspapers show, for instance, that lenders in Rotterdam and Amsterdam united and protested against the Discipline Act rather late. While parliamentary debate took off in May I855, these lenders only gathered on I9 February and 3 March I 856 respectively and decided, in line with the centuries-old Dutch tradition of submitting petitions to lawmakers, to petition parliament. It is worth noting that shopkeepers and boardinghouse keepers petitioned many months after the captains (December I855 to February I 856) as well as the Chambers of Commerce (May and June I 855), who both primarily focused on the Act's articles unrelated to credit. ${ }^{13}$ That lenders put the Discipline Act high on their agendas relatively late suggests that they had either been unaware of the ongoing parliamentary debates or that they expected lawmakers to develop a transitional arrangement after being petitioned with reasonable arguments. Regardless of which was the case, lending strategies would not or only very briefly have been adjusted because the Minister of Justice already sympathised with the petitioners in parliament on I 5 April. ${ }^{14}$ The 1856 ledger thus provides an encompassing overview of the credit market for seafarers as it existed when the Discipline Act became effective. ${ }^{15}$

\section{III}

During the month of July I 856 a group of 252 lenders presented I3,708 IOUs, amounting to around 4I6,000 guilders, for registration in the water bailiff's ledger. IOUs that survived in the estates of deceased seafarers, which were settled by the water bailiff, show that these were handwritten contracts as well as pre-printed forms. Large lenders typically relied on forms that also pre-printed their names and smaller lenders used forms to which they added their names by hand. ${ }^{16}$ At least

13 For the newspapers, see Algemeen Handelsblad, 2 I February i 856, I March I 856, 3 March I 856 and 5 March I856; De Tijd, 22 February I856; Nieuwe Rotterdamsche Courant, 5 March I856; Utrechtsche Provinciale en Stads-Courant, 5 March I856. For the petitions, see Dutch National Archive, Archief van de Tweede Kamer der Staten-Generaal, I8I5-I945 (entry no. 2.02.22), inv. nos. I067 (nos. 4I9, 482), IO68 (no. 29), IO69 (nos. 233-7, 3I 5, 364), IO70 (nos. 479-8 I, 537) and Io7I (nos. 7I2, $733,743)$.

14 Handelingen der Tweede Kamer, i 856 (I 5 April).

15 Even if some had in fact briefly reduced lending, this would merely strengthen the point made here that Amsterdam's market for seafarer loans was substantial.

16 ACA, Waterschout, inv. nos. I56-7I. The estates also contain pre-printed IOUs from Dordrecht, Middelburg, Purmerend and Rotterdam. This suggests that, whilst port size and the sophistication of local financial markets may have favoured credit markets for seafarers in Amsterdam and Rotterdam, they also developed in the second- and third-rank Dutch ports. See Handelingen der Staten-Generaal, I839-4O, pp. 294-5; I840-I, p. II95; I84I-2, p. 625; I842-3, p. I584; I843-4, p. 7I 3; I 844-5, p. I244; I 845-6, p. 690; Statistisch Jaarboek der Gemeente Amsterdam II, p. I 57; Jonker I 996. 
one of the large lenders, Cas Spijker, also kept account books and provided receipts for the goods that seafarers purchased. ${ }^{17}$ The IOU was pivotal, however, as it had to be presented to the water bailiff to collect wage payments and to record repayments on.

Four characteristics of the IOUs deserve mentioning. First, specifications of the goods and services that were received on credit are usually absent. ${ }^{18}$ Though the occupation of the lender is sometimes mentioned on the IOU, it can also be retrieved from additional sources. This way some insight can still be obtained about the goods and services involved (see Section IV). Second, loan repayments were contingent on the ship's safe journey (behouden reis) and the interest rate was implicit. Lenders added a premium - IO, I5 and 20 per cent seem to have been common - to the value of the goods and services that they provided. ${ }^{19}$ Third, new loans were not always recorded on a new IOU. While Cas Spijker did document his I 839 and I84I loans to Jonas Aberg on two separate forms, it was not uncommon to add new loans on the reverse of an IOU after an initial repayment. In one such case, a seafarer's wife purchased additional goods on credit - including children's shoes (kinder schoenen) - on three occasions while her husband was at sea. ${ }^{20}$ Fourth, full or partial repayments were recorded on the IOU and signed for by the lender and water bailiff. The latter also recorded these payments in his account books. ${ }^{21}$

After a seafarer returned to port his wages were used to repay his lenders. ${ }^{22}$ When he had earned enough he repaid his lenders in full, but in many cases lenders received a partial payment in proportion to the size of their loans. Unredeemed sums were deferred to a future journey and then took priority over the more recent loans a seafarer might have contracted for that new journey. When subsequent payments were not made or when again they did not suffice, loans eventually ended up in the water

17 ACA, Waterschout, inv. no. I7I (scans 670, 763).

18 For exceptions, see ACA, Waterschout, inv. no. I7I (scans 285, 3 I I, 539).

19 Van Bochove 20I4; ACA, Waterschout, inv.nos. I 58 (scans 55, 342, 875), I 59 (scans 453, 459, 578, 678,732 ), I 59 (scan 772), I69 (scans I 70, 535, 659, 867, 978) and I 7 I (scans 3 IO, 539, 708). As actual interest rates depended on seafarers' repayment schedules they thus differed from one seafarer to another. Establishing them systematically is impossible, however, because premiums were infrequently recorded on IOUs and because the IOUs in seafarers' estates were hardly ever repaid in full. See Van Bochove 2014 on interest rates on seafarer loans during the eighteenth century.

20 ACA, Waterschout, inv. nos. I 59 (scans 549, 550, 555, 556) and I 7I (scans 60, 62, 78, 7I3, 7I4).

21 ACA, Waterschout, inv. nos. I72-7.

22 Acting against the safe journey clause in the IOUs, the water bailiff had resorted to also making repayments from unclaimed estates of deceased seafarers. In these instances the lenders usually guaranteed to reimburse these sums in case inheritors presented themselves. The debts of Carl Eriksen are a good example of the practice. During his service Eriksen earned I 20 guilders of which he pocketed 65 himself. Adding the proceeds of auctioning his possessions (60.95 guilders) and subtracting a contribution to the benevolent society Zeemanshoop (3 guilders), a sum of I 12.95 guilders remained for repaying debts totalling 23I.57 guilders to his four lenders. In situations like this lenders accepted that this final payment settled the seafarer's debt. ACA, Waterschout, inv.nos. I7I (scans 222-4) and I75 (scan IOO). This practice was also common at the Dutch East India Company. See Van Bochove, Milo and Van Velzen 20 i 8. 
bailiff's ledger of July I 856 . This is, for instance, why prominent lender J. W. van Recken registered a debt of I 8.65 guilders that seafarer J. Butter had owed him since May I 840 . The water bailiff's account books contain evidence of this: on I I May I 840 Butter paid half of the 37.30 guilders that he owed Van Recken, leaving I 8.65 guilders for later journeys. Additional payments never took place, however, and Van Recken duly registered the unredeemed amount in the I 856 ledger. Scribbles in this ledger sometimes refer to these past partial payments as 'last payment' (laast voldaan) and 'remaining' (rest). ${ }^{23}$ The I 856 ledger thus contains a mix of such old, non-performing loans as well as many recent loans on which repayments had not yet been made.

Except for the heterogeneous names of borrowers, all information in the water bailiff's ledger was entered into a database. ${ }^{24}$ While the unredeemed amount was recorded for all but one IOU, the date of the (last repayment on the) loan was included less meticulously. For a large majority of the IOUs (75.7 per cent) the date was complete, but a substantial share of the entries (20.5 per cent) did not contain a day. The phenomenon was driven largely by the IOUs registered by a few prominent lenders. In the case of W. P. Kohl (424 out of 425 IOUs) days were often not recorded on his IOUs that survived in the estates of deceased seafarers. However, H. Lond (I,3 I 2 out of I,3 I4 IOUs), J. W. van Recken (296 out of 302 IOUs) and W. G. Fiege (I 87 out of I 87 IOUs) typically recorded full dates on their IOUs. In these cases the water bailiff's clerks were most likely responsible for not copying the day recorded on the IOUs. ${ }^{25}$ For an additional 2.2 per cent of the IOUs the year was available, but not the day and month. Only I.5 per cent of the IOUs could not be assigned to a specific year, but as the temporal analysis below focuses on the year of the (last repayment on the) loan, this fraction is negligible.

Figure I shows the distribution of the years of the (last repayment on the) loans registered in the water bailiff's ledger. The substantial number of recent years was driven by loans made in I 855 and I 856 on which no, or only partial, repayments had been made as well as by first and subsequent repayments on older loans. The distribution's relatively long and decreasing tail also shows, however, that repayments had not recently been made on many other older loans. That numerous (last repayments on) loans were made more than five years before the ledger was put together suggests that a fair share of the new loans provided each year to seafarers (see below) performed poorly. It is important to realise, however, that lenders undoubtedly

23 ACA, Waterschout, inv. nos. I72 (scan 80) and I78 (scans 90, I 50).

24 The database will be deposited at DANS (https://easy.dans.knaw.nl).

25 For Kohl, see ACA, Waterschout, inv. nos. I69 (scans 288, 3 I 4, 879, 902) and I 7 I (scans 337, 656, 665, 7I 5). For Lond, see inv. nos. I69 (scans 64, I43, 2 I 7, 562, 576, 6 I I , 6I 5, 642, 689, 7 I 8, 767, 786, 798, 923, 940) and I7I (scans 20, 55-6, 60, I 5 I , 4I 7, 69I). For Van Recken (who also spelled his name as Von Reeken), see inv. nos. I69 (scans 430, 486, 556, 640, 692, 982) and I I I (scans I 53, 284, 323, 377, 4I9, 480, 54I, 584, 598). For Fiege, see inv. nos. I69 (scan 379) and I7I (scan 667). 


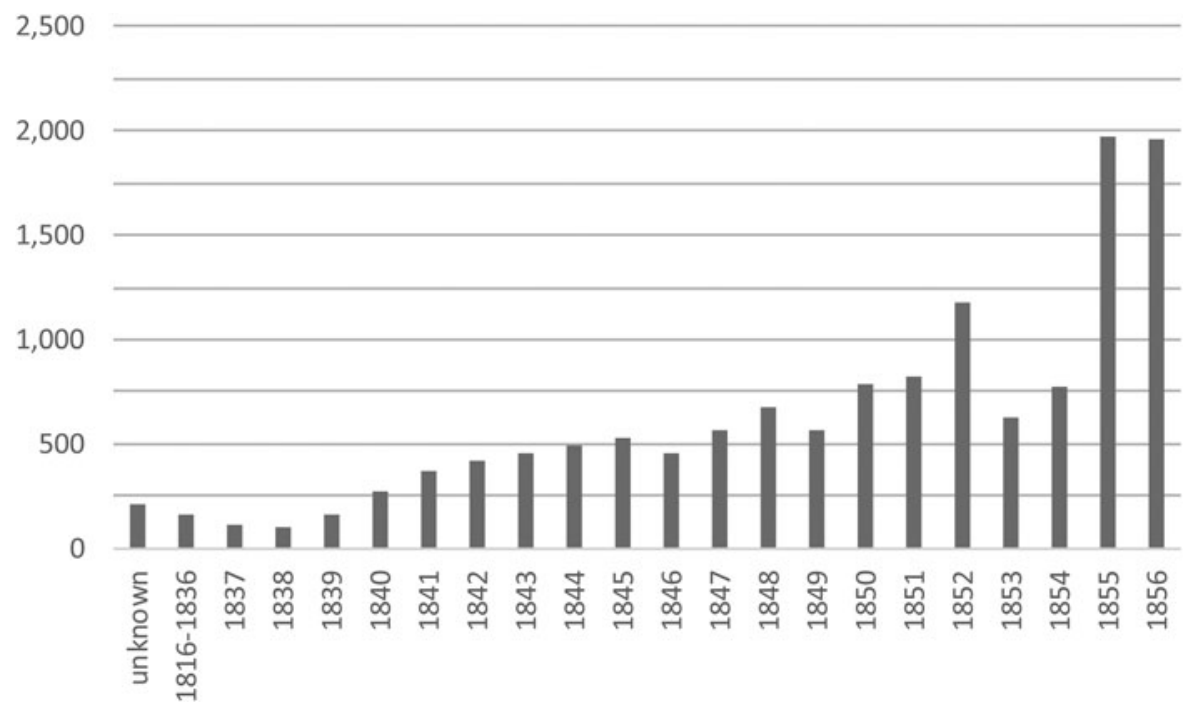

Figure I. The years of the (last repayment on) loans

Source: Database register waterschout.

anticipated on (partial) defaults when choosing their premiums and setting the pricequality ratio of their goods and services.

Figure 2 builds on Figure I by showing percentile distributions of the unredeemed amounts. A straightforward interpretation of the data is complicated, as the ledger combined loans on which no repayments had been made with loans that were partially repaid. The 50 th and 95 th percentiles of each year group are nevertheless helpful for shedding light on the credit market for seafarers. The 95th percentile, for instance, will mainly have consisted of large loans on which no repayments had been made. The fact that the corresponding values for old as well as recent loans did not typically exceed 90 guilders is illustrative. Some loans were of course larger, but usually not by much: only 66 of the unredeemed amounts were for 200 guilders or more and only two of them exceeded 600 guilders (i.e. one for I,030 guilders and one for I, 800 guilders). These values suggest that while IOUs did not usually exceed 200 guilders, most of them will have been smaller than 90 guilders. The 50 th percentile, in turn, gives an impression of the lower bound of the value of new IOUs because loans below the 5oth percentile will have consisted disproportionately of partially repaid loans. The modest U-shaped pattern of the 5oth percentile is consistent with this as it points to the presence of relatively many fully unredeemed loans among older (because fewer partially repaid loans would still be included) and more recent dates (because full and partial repayments had not yet been made). Figure 2 hence suggests that new seafarer loans most likely ranged between 20 and 90 


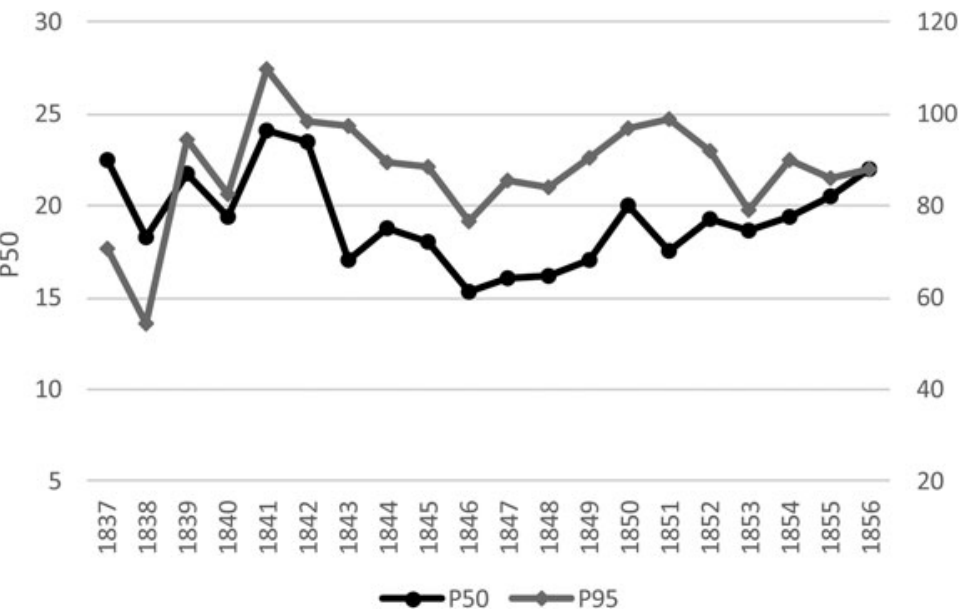

Figure 2. The percentile distribution of the (remaining) loan values by year of the (last repayment on the) loan (in guilders)

Source: Database register waterschout.

guilders. ${ }^{26}$ These modest loan sizes notwithstanding, the credit market for seafarers managed to reach a substantial overall size.

\section{V}

As lenders brought their IOUs to the water bailiff to have them registered in the ledger, their loans were usually recorded in it on one day and in consecutive series. There were a few exceptions to this (see Section II), so that in a number of instances lenders had to be linked in order to derive unique persons. However, because the lenders constituted a relatively confined group and because the type of credit was very specific, the risk of falsely linking lenders was small. After completing the linking procedure, 252 unique lenders remained. This number in itself suggests that a sizeable and diverse group of people commonly lent to seafarers and felt safe to do so.

To shed more light on the background of the most prominent lenders, information was collected from three additional sources. The IOUs available in the estates of deceased seafarers were considered first because these most likely belonged to the lenders actually being scrutinised. The local address book was consulted next as it

26 These values are consistent with the amounts recorded on 246 IOUs of one lender, Cas Spijker, which have survived in the archives and which are discussed in more detail below. Here the 5oth, 95th and 99.5th percentiles (cf. the 66 unredeemed amounts discussed in the text) had values of 38.30, I30.I9 guilders and I77.77 guilders respectively, while the largest IOU amounted to 205.60 guilders. 
was less specific than the IOUs, but still not too general. The address book included many shopkeepers and thus more likely referred to the lenders under review than more general sources would. Since the IOUs considered cover the period I 834-5I, the $1850-\mathrm{I}$ edition of the address book was used. Finally, the $185 \mathrm{I}-3$ population register was checked. ${ }^{27}$ Through these sources information was obtained on name, address, occupation, goods and services provided on credit, minimum career period, date of birth and place of origin. Tables I and 2 present the results for the largest lenders (i.e. those with a I per cent or larger share in the overall unredeemed debt) as well as for groups of lenders who did not meet this criterion. ${ }^{28}$

Table I shows that there existed two groups of lenders: a substantial group whose involvement was infrequent and modest as well as a smaller group whose involvement was frequent and substantial. Some of the latter were no longer alive and others had retired from lending, as witnessed by the share of (last repayments on) loans registered for 1855 and I 856 , but others were still very active. The more important lenders not only registered I 5.9 times as many unredeemed loans on average (I2.I times without Spijker and Lond), but their unredeemed loans were also 56 per cent larger on average. As a result, this group claimed 24.8 times larger sums of money on average (20.3 times without Spijker and Lond). As the largest lenders (9.9 per cent of the number of lenders) combined for 63.6 per cent and 73.2 per cent of the registered number and value of IOUs respectively, Tables I and 2 give a good insight into the most important players in this credit market.

From Table 2 it becomes clear that the largest lenders had the occupations familiar from the descriptions of sailor-towns: tailors, cobblers, shopkeepers, drink sellers and boarding-house keepers. They were also situated in those parts of town where one would expect to find them: the sailor-town in the eastern part of Amsterdam (i.e. Geldersche Kade, Nieuwmarkt, Zeedijk and Nieuwebrugsteeg) and the shopping district in the western part of Amsterdam (i.e. Nieuwendijk, Kolksteeg and

27 ACA, Waterschout, inv. nos. I69-7I (only the pre-printed IOUs were analysed); Amsterdam City Archive, Collectie Stadsarchief Amsterdam: Adresboeken (entry no. 30274) (henceforth ACA, Adresboeken), inv. no. I I; Amsterdam City Archive, Archief van het Bevolkingsregister (entry no. 5000) (henceforth ACA, Bevolkingsregister), inv. nos. 258-994 (consulted through https://archief. amsterdam/indexen/bevolkingsregisters_1851-1853/zoek/index.nl.html). The details of some addresses were completed through His GIS Amsterdam, which was linked to the I85I-3 population register (www.hisgis.nl/hisgis/gewesten/amsterdam/kaart1860/amsterdam1860).

${ }^{28}$ A $0.5 \%$ threshold was rejected because it almost halved the retrievable information and made incorrect matches more likely. Reconstructing the cases of H. Lond, A. Hensmans and Widow C. J. Caspers required information from a fourth source: newspaper advertisements. These showed that Hendrik Lond died in I833, but that Jan Coenraad Londt married his widow (Wilhelmina Maria Schweeke) and continued the business under the name 'H. Lond'. A marriage announcement revealed that Hensmans was incorrectly included in the digitised population register as 'Hezemans'; mention of his wife, Dorothea Timmers, in an advertisement established this. Announcements of a 25 th wedding anniversary and a death showed that C. J. Caspers had been married to Antje van Ammers, who was in fact included in the population register. See Algemeen Handelsblad, 22 November I 832, I 4 June I 833, 7 February i 835, 23 November I 847 and I April I 850. 
Table I. Descriptive statistics of the lenders

\begin{tabular}{|c|c|c|c|c|c|c|c|c|c|}
\hline \multirow[b]{2}{*}{ Name } & \multicolumn{3}{|c|}{ Lender } & \multicolumn{3}{|c|}{ Number of IOUs } & \multicolumn{3}{|c|}{ Value (remaining) of IOUs } \\
\hline & Period & $\mathrm{N}$ & $\% \Sigma \mathrm{N}$ & $\mathrm{N}$ & $\% \Sigma N$ & $\% \mathrm{~N}$ in $1855^{-6}$ & Guilders & $\% \Sigma$ Guilders & Average \\
\hline C. Spijker & I $834-56$ & I & $0.4 \%$ & $\mathrm{I}, 294$ & $9.4 \%$ & I.I $\%$ & 53,429 & $\mathrm{I} 2.8 \%$ & $4 \mathrm{I} \cdot 3$ \\
\hline J. R. Sachtleben & I $825-56$ & I & $0.4 \%$ & 436 & $3.2 \%$ & $40.8 \%$ & 24,480 & $5.9 \%$ & 56.1 \\
\hline H. Lond & I $839-56$ & I & $0.4 \%$ & $\mathrm{I}, 3 \mathrm{I} 4$ & $9.6 \%$ & $38.2 \%$ & $2 \mathrm{I}, 045$ & $5.1 \%$ & I6.0 \\
\hline J. H. Timmerman & I $84 \mathrm{I}-56$ & I & $0.4 \%$ & 346 & $2.5 \%$ & $0.6 \%$ & I7,024 & $4.1 \%$ & 49.2 \\
\hline C. H. Jansen & I $846-56$ & I & $0.4 \%$ & 392 & $2.9 \%$ & $4 \mathrm{I} .6 \%$ & I 5, I 4 I & $3.6 \%$ & 38.6 \\
\hline A. Hensmans & I $836-56$ & I & $0.4 \%$ & $4 \mathrm{OI}$ & $2.9 \%$ & I I. $7 \%$ & I 3,473 & $3.2 \%$ & 33.6 \\
\hline W. P. Kohl & I $830-56$ & I & $0.4 \%$ & 425 & $3.1 \%$ & $0.5 \%$ & $\mathrm{I} 3,407$ & $3.2 \%$ & $3 \mathrm{I} \cdot 5$ \\
\hline G. Steenhoff & I $835-56$ & I & $0.4 \%$ & 430 & $3.1 \%$ & $30.9 \%$ & I 3,292 & $3.2 \%$ & 30.9 \\
\hline J. A. Rijks & I $837-56$ & I & $0.4 \%$ & 363 & $2.6 \%$ & $39.4 \%$ & I 2,640 & $3.0 \%$ & 34.8 \\
\hline B. J. Kohl & I 8 I $6-56$ & I & $0.4 \%$ & 300 & $2.2 \%$ & $61.7 \%$ & I I, 957 & $2.9 \%$ & 39.9 \\
\hline Widow C. J. Caspers & I $840-56$ & I & $0.4 \%$ & 235 & I. $7 \%$ & $36.2 \%$ & II, 608 & $2.8 \%$ & $49 \cdot 4$ \\
\hline G. Pluimker & I $836-56$ & I & $0.4 \%$ & $4 \mathrm{I} 3$ & $3.0 \%$ & $2 \mathrm{I} .8 \%$ & I I, I I 8 & $2.7 \%$ & 26.9 \\
\hline J. W. van Recken & I $83 I-53$ & I & $0.4 \%$ & 302 & $2.2 \%$ & $0.0 \%$ & $\mathrm{IO}, 542$ & $2.5 \%$ & 34.9 \\
\hline W. G. Fiege & I $834-55$ & I & $0.4 \%$ & I 87 & I. $4 \%$ & I.I $\%$ & 8,497 & $2.0 \%$ & $45 \cdot 4$ \\
\hline H. A. Kokenge & I $839-56$ & I & $0.4 \%$ & 273 & $2.0 \%$ & $53 \cdot 5 \%$ & 8,357 & $2.0 \%$ & 30.6 \\
\hline J. H. Sachtleben & I $840-56$ & I & $0.4 \%$ & 292 & $2.1 \%$ & $4 \mathrm{I} .8 \%$ & 8,249 & $2.0 \%$ & 28.2 \\
\hline J. Feijs & I $840-56$ & I & $0.4 \%$ & 202 & I. $5 \%$ & $46.5 \%$ & 7,830 & І. $.9 \%$ & 38.8 \\
\hline O. Christiansen & I $832-56$ & I & $0.4 \%$ & I 54 & I.I $\%$ & $29.9 \%$ & 6,445 & I. $5 \%$ & 4I.8 \\
\hline N. Feis & I $852-56$ & I & $0.4 \%$ & 206 & I. $5 \%$ & $75.2 \%$ & 6,238 & I. $5 \%$ & 30.3 \\
\hline H. C. Petersen & I $837-56$ & I & $0.4 \%$ & I I 6 & $0.8 \%$ & $20.7 \%$ & 5,926 & I. $4 \%$ & 5I.I \\
\hline J. Schrager & I $830-56$ & I & $0.4 \%$ & $\mathrm{I} 48$ & I.I $\%$ & $40.5 \%$ & 5,360 & I. $3 \%$ & 36.2 \\
\hline J. H. Klönne & I $837-56$ & I & $0.4 \%$ & I 59 & І. $2 \%$ & $6.9 \%$ & 5,236 & I. $3 \%$ & 32.9 \\
\hline L. Fopma & I $840-56$ & I & $0.4 \%$ & 97 & $0.7 \%$ & $37.1 \%$ & $4,70 \mathrm{I}$ & I. $1 \%$ & 48.5 \\
\hline P. C. Pedersen & I $844-56$ & I & $0.4 \%$ & $\mathrm{I} 2 \mathrm{O}$ & $0.9 \%$ & $60.8 \%$ & 4,199 & І.०\% & 35.0 \\
\hline A. Dussman & I $848-56$ & I & $0.4 \%$ & I I 6 & $0.8 \%$ & $4 \mathrm{I} .4 \%$ & $4, \mathrm{I} 72$ & I.०\% & 36.0 \\
\hline
\end{tabular}




\begin{tabular}{|c|c|c|c|c|c|c|c|c|c|}
\hline I.O\% $\leq \mathrm{X}$ & I 8 I $6-56$ & 25 & $9.9 \%$ & $8,72 \mathrm{I}$ & $63.6 \%$ & $27 . \mathrm{I} \%$ & 304,367 & $73.2 \%$ & $34 \cdot 9$ \\
\hline $0.5 \% \leq X<1.0 \%$ & I $829-56$ & I I & $4.4 \%$ & $\mathrm{I}, \mathrm{I} 36$ & $8.3 \%$ & $37.7 \%$ & $30,24 \mathrm{I}$ & $7 \cdot 3 \%$ & 26.6 \\
\hline $0.25 \% \leq \mathrm{X}<0.5 \%$ & I $824-56$ & 29 & I I. $5 \%$ & $2, I 62$ & I $5.8 \%$ & $29.9 \%$ & 42,066 & IO.I $\%$ & I9.5 \\
\hline $0 \%<\mathrm{X}<0.25 \%$ & I $83 I-56$ & I 87 & $74.2 \%$ & I,689 & I $2.3 \%$ & $29.6 \%$ & 39,306 & $9.4 \%$ & $23 \cdot 3$ \\
\hline Overall & & 252 & I0O.0\% & I 3,708 & IOO. $\% \%$ & & 4 I 5,980 & IOO.O\% & 30.3 \\
\hline
\end{tabular}

Source: Database register waterschout. 
Table 2. Information about the major lenders

\begin{tabular}{|c|c|c|c|c|}
\hline $\begin{array}{l}\text { Name in } \\
\text { population register }\end{array}$ & $\begin{array}{l}\text { Place } \\
\text { of birth }\end{array}$ & $\mathrm{Age}^{\mathrm{a}}$ & Address & Occupation \\
\hline Cas Spijker & Amsterdam & 50 & Geldersche Kade 48 & Shopkeeper (tobacco) \\
\hline $\begin{array}{l}\text { Johan Rudolph } \\
\text { Sachtleben }\end{array}$ & Germany & 44 & Nieuwmarkt 4 & Shopkeeper/tailor \\
\hline Jan Coenraad Londt & Amsterdam & 46 & Zeedijk 87 & Shopkeeper/merchant \\
\hline $\begin{array}{l}\text { Johan Hinrich } \\
\text { Timmerman }^{\text {b }}\end{array}$ & Germany & - & Nieuwendijk I63 & Tailor \\
\hline $\begin{array}{l}\text { Casparus Hendrikus } \\
\text { Jansen }\end{array}$ & Amsterdam & 35 & Nieuwendijk 95 & Shopkeeper/tailor \\
\hline $\begin{array}{l}\text { Antonius } \\
\text { Hensmans }\end{array}$ & Amsterdam & 48 & Nieuwmarkt 27 & Shopkeeper/tailor \\
\hline $\begin{array}{l}\text { Wilhelm Petrus } \\
\text { Kohl }\end{array}$ & Amsterdam & 49 & Nieuwendijk I 50 & Shopkeeper \\
\hline Gerhard Steenhoff & Amsterdam & 28 & $\begin{array}{l}\text { O.Z. Voorburgwal } \\
\text { I37 }\end{array}$ & Tailor \\
\hline $\begin{array}{l}\text { Johannes Arnoldus } \\
\text { Rijks }\end{array}$ & Amsterdam & 47 & Nieuwendijk I07 & Shopkeeper/tailor \\
\hline $\begin{array}{l}\text { Bernardus Johannes } \\
\text { Kohl }\end{array}$ & Amsterdam & 46 & Zeedijk i I6 & $\begin{array}{l}\text { Shopkeeper (woollens } \\
\text { and manufactures) }\end{array}$ \\
\hline Antje van Ammers & Amsterdam & 6I & Wijde Kapelsteeg 3 & Boarding-house keeper \\
\hline Geert Pluimker & Germany & 55 & Teertuinen I9 & $\begin{array}{l}\text { Shopkeeper (clothing } \\
\text { and manufactures) }\end{array}$ \\
\hline J. W. van Recken ${ }^{c}$ & Germany & - & Nieuwmarkt 974 & Clothing \\
\hline $\begin{array}{l}\text { Willem Georg } \\
\text { Fiege }\end{array}$ & Netherlands & 69 & Texelsche Kade io & Shopkeeper/tailor \\
\hline $\begin{array}{l}\text { Hendrik Antoon } \\
\text { Kokenge }\end{array}$ & Germany & 47 & Nieuwendijk Io6 & Tailor \\
\hline $\begin{array}{l}\text { Johan Hendrik } \\
\text { Sachteleben }\end{array}$ & Germany & 48 & Zeedijk 49 & Shopkeeper/tailor \\
\hline Johannes Feijs & Amsterdam & 54 & Haarlemmerdijk 273 & Tailor \\
\hline Oele Christiaanse & Denmark & 39 & Geldersche Kade 36 & Drink seller \\
\hline Nicolaas Feis & Netherlands & 34 & Nieuwebrugsteeg 5 & Grocer \\
\hline $\begin{array}{l}\text { Hans Christiaan } \\
\text { Petersen }\end{array}$ & Denmark & 43 & Warmoesstraat I i 8 & Boarding-house keeper \\
\hline Jacob Schrager & Germany & 53 & Wijde Kapelsteeg 5 & Boarding-house keeper \\
\hline $\begin{array}{l}\text { Johan Heinrich } \\
\text { Klönne }\end{array}$ & Germany & 54 & Kolksteeg 26 & Tailor \\
\hline Louw Fopma & Netherlands & 45 & N. Z. Armsteeg 3 I & Boarding-house keeper \\
\hline $\begin{array}{l}\text { Pieter Christiaan } \\
\text { Petersen }\end{array}$ & Denmark & $4 \mathrm{I}$ & Wijde Kapelsteeg 4 & Boarding-house keeper \\
\hline Albert Duszmann & Germany & 33 & Kapelsteeg 9 & Drink seller \\
\hline
\end{tabular}


Notes to Table 2:

${ }^{a}$ The age of the lenders refers to their age on 30 July i 856 , the last day on which loans were recorded in the water bailiff's ledger.

b Algemeen Handelsblad, 3 April I 855, shows that J. H. Timmerman was no longer alive when the ledger was compiled.

${ }^{c}$ Van Recken was born on 2 November 1794 in Phiesewarden near Blexen, which his marriage certificate (dated 7 October I 829) listed as his place of origin. He died in October I 843 and his wife continued the 'renowned' store until her death in January I845. Van Recken's death is corroborated by the fact that on the reverse of his IOUs it is indicated that payments were subsequently received by his widow and heirs. See Auswanderer aus dem Großherzogtum Oldenburg (www.auswanderer-oldenburg.de/getperson.php?personID =I767 58\&tree=Auswanderer); WieWasWie (www.wiewaswie.nl/nl/detail/35433099); Algemeen Handelsblad, 2 November I 843, I 7 January I 845, 5 February I 845 and I 4 March I 845; ACA, Waterschout, inv. nos. I69-7I. Van Recken's address was taken from the I $843-4$ address book. See ACA, Adresboeken, inv. no. 7.

Source: Table I; notes 26 and 27.

N.Z. Armsteeg). Boarding-house keepers occupied a rather modest position among the top lenders. This suggests that they obtained (part of) the two months' wage advance that seafarers received when they mustered.

The tables suggest that in I856 the largest lenders were typically males born in Amsterdam, who were in their forties or fifties and who had been active as lenders for several decades. The top 25 was completed by lenders with more varied backgrounds. The presence of lenders born elsewhere in the Netherlands as well as those born in Denmark and Germany stands out and is consistent with what is known about migration and the Amsterdam labour market. The occupations that involved providing credit to seafarers were apparently sufficiently open to outsiders to allow them to become substantial lenders quickly (Van Lottum 2007; Hell 2017). Besides lenders of non-Amsterdam origin, the presence of the widow of C. J. Caspers points to the involvement of another interesting group. While the top 25 counted only one widow, the ledger actually contained 30 others (see above). At least one of these, the widow of $\mathrm{W}$. Louwes, used a form that also pre-printed her name. The fact that widows successfully continued to supply loans suggests that they had already been closely involved in the businesses of their husbands when they were still alive. ${ }^{29}$

The size and diversity of the group of lenders raises the question of how they could be assured that seafarers would not run up debts across town beyond their capacity to repay. While the water bailiff's service of making loan repayments from seafarers' wages solved the moral hazard problem, it did not protect lenders against the risks of adverse selection. The fact that the credit market for seafarers had existed for so long, and that so many and diverse lenders participated in it, suggests that a

29 ACA, Waterschout, inv. no. I7I (scan 437). 
mechanism existed to mitigate adverse selection. Did long-term relationships between lenders and borrowers perhaps play a role? Or did boarding-house keepers play an intermediary role by, for instance, lodging their compatriots or by only referring their guests to specific shopkeepers (Hell 20 I 7)? Current knowledge about how lenders conducted their businesses is unfortunately still insufficient to answers such questions. Section $\mathrm{v}$ therefore takes a first step by reconstructing the daily operations of one major lender for whom several sources were available in addition to the water bailiff's ledger.

Cas Spijker was the most important lender in the water bailiff's ledger: numerically he missed first place by just 2 I loans, but financially he ranked first by far (see Table I). Spijker was born in Amsterdam on 7 February I 806 and, according to the population registers of the period I $85 \mathrm{I}-6$, he lived at Geldersche Kade 48 - or 453 according to the new house numbering system introduced in I 853 - with his wife, six to eight children and one maid. The population register listed Spijker as a shopkeeper (winkelier) and based on his lending he must have been operating as such since at least I833. It is unclear where his shop was located then, but the I837-8 edition of a local address book situated it at Geldersche Kade 53 (where in the I836-7 edition another shop was still located). In a January I 843 advertisement in Algemeen Handelsblad Spijker announced the relocation of his shop to Geldersche Kade 48 . In this advertisement he also mentioned that he ran a business 'in Tobacco, etc., etc., etc., etc.'. That he indeed sold more than just tobacco is demonstrated by an IOU from 1848 in which a ship's carpenter confirmed that he owed Spijker money for ship's carpenters' tools, tobacco, coffee, soap, cigars and other unspecified goods. Despite this wide variety of goods, the local address books included Spijker as 'shopkeeper and merchant in tobacco' (winkelier en koopman in tabak) or simply as 'in tobacco' (in tabak). Spijker thus seems to have operated a general store for seafarers with a focus on tobacco. Interestingly, Spijker was also responsible for organizing support for unfortunate neighbours as a commissioner of his neighbourhood. ${ }^{30}$

Besides the ledger, the water bailiff's archive contains additional sources that shed light on Spijker's lending. As the water bailiff was responsible for settling the estates of deceased seafarers, his archive holds many of the original IOUs presented by lenders to claim (partial) repayments from the seafarers' estates. This collection contains, among others, 246 IOUs from Spijker. ${ }^{31}$ These IOUs cover the period I $833-52$

${ }^{30}$ Van Wageningen 2002; ACA, Bevolkingsregister, inv. nos. 434 (scan I I3) and 436 (scan I98); ACA, Waterschout, inv. nos. I58 (scan 2I) and I65 (scan I70); Gepriviligeerd naamregister der heeren kooplieden, I 836-7, 46; I 837-8, I07; Algemeen adres-boek of naamregister van de notabelste inwoners der stad Amsterdam, I 839-4O, 24I; I84I-2, 242; I843-4, 242; I 845-6, 244; I 846-7, 248; I848-9, 244; I 85O-I, 240; Algemeen Handelsblad, 23 January I843, 9 May I853, 22 February I855 and 23 October I855; De Tijd, 25 December I 85 I.

31 ACA, Waterschout, inv. nos. I $56-7$ I. 
and were all pre-printed. ${ }^{32}$ The initial form, in use between I 833 and I 838 , was fairly simple. An analysis of the I 838 forms revealed that Spijker then used two types of form: one on which the rank of sailor was pre-printed and one on which the rank was left blank. The use of such dedicated forms suggests that lending must already have been substantial by this time. In the years that followed, Spijker used an even broader set of dedicated forms. Four forms existed to record combinations of rank (sailor or blank) and literacy (with a special clause in case of illiteracy). ${ }^{33}$ At some stage a pre-printed field for seafarers' ages was incorporated into the form as well.

Spijker typically recorded the rank, destination and boarding-house keeper of his borrowers. The latter might point to relationships between boarding-house keepers and lenders as a solution to adverse selection problems. However, based solely on Spijker's IOUs, it cannot be established decisively whether these relationships were exclusive and indeed whether they protected lenders sufficiently. Rank and destination, which were recorded together on 243 of the 246 IOUs, are fortunately easier to interpret. Sailors dominated with I95 IOUs and were followed by carpenters (9), sailmakers (9), cooks (7), boatswains (6), boatswains' mates (6), junior sailors (6), medical doctors (2), ship's stewards (2), a cooper and a helmsman. ${ }^{34}$ Except for three seafarers who sailed within Europe, these seafarers sailed on the long-distance routes to Batavia, capital of the Dutch East Indies (2 I 8), Surinam (I I), the Guinea coast (9) and South America (2). ${ }^{35}$ The most common combination of rank and destination was the sailor going to Batavia (I76). It is not surprising that this particular group dominated the IOUs found in the estates settled by the water bailiff. Because of the long voyage they presumably relied on credit more frequently than seafarers on other routes. In addition to this, crews on this route were large and numbered many sailors. With long voyages and the prevalence of tropical diseases, the absolute number of deceased sailors on this route must have been higher than that on other routes. It is therefore logical that sailors on the route to Batavia dominated the estates of deceased seafarers settled by the water bailiff.

The number of annual observations for most rank-destination combinations is too small to generalise, but the number of sailors going to Batavia is large enough to determine how borrowing within this particular group developed over time. Figure 3 suggests that the median loan of these borrowers increased substantially, but continued to fall within the 20 to 90 guilders range of new loans as found above. As Spijker was born in I806, the increase points to a process through which he - as a young shopkeeper - established how much he could lend to particular rank-destination

32 On pre-printed IOUs, see Van Bochove and Kole 20I4.

33 The IOUs of illiterate seafarers were typically signed by witnesses. See, for instance, ACA, Waterschout, inv. no. I64 (scans 46, 480, 934). The presence of signatures, whether of seafarers or their witnesses, probably prevented lenders from counterfeiting IOUs.

34 The seafarers with the unknown destinations were two sailors and a carpenter.

35 There were no clear trends over time in the share of sailors in ranks and Batavia in destinations. 


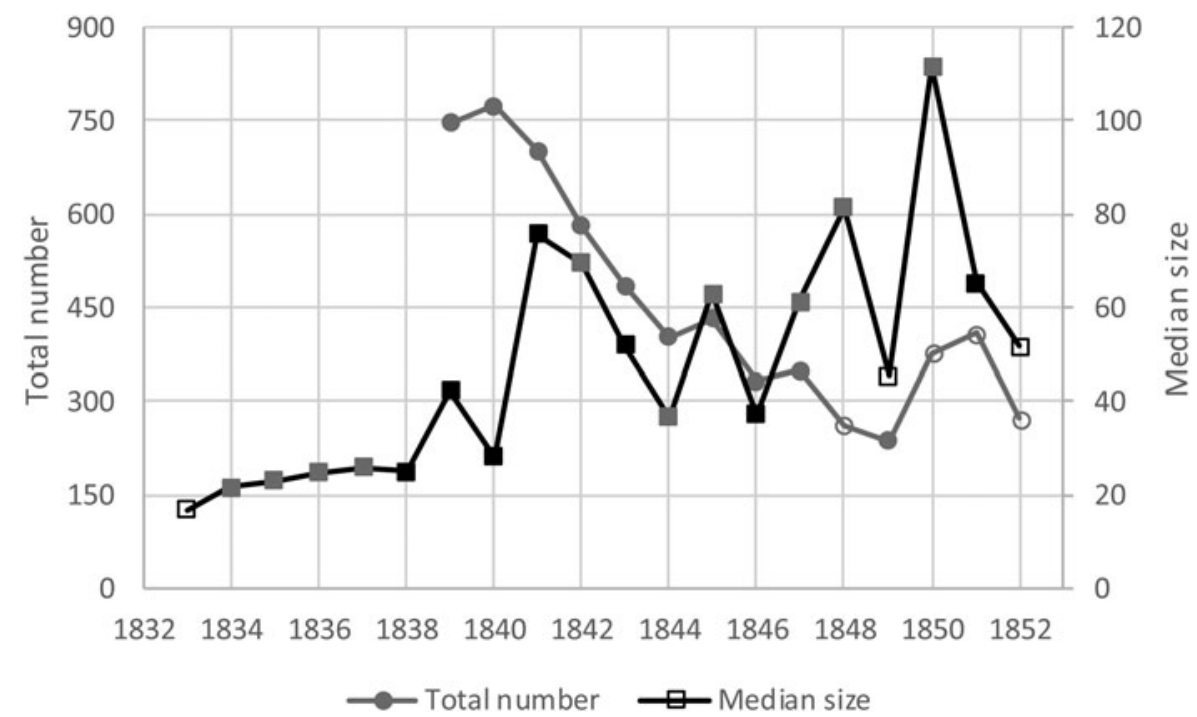

Figure 3. The total number of loans provides by Cas Spijker and the median size of his loans contracted by sailors going to Batavia (in 1839 guilders)

Note: For the total number of loans series the grey markers indicate that the highest serial number came from November or December. For the median loan size series the black markers indicate that ten or more observations were available, the grey markers five to nine and the white markers fewer than five.

Source: ACA, Waterschout, inv. nos. I 58 (scans 94, I43, I 8 I, 235, 255, 276, 305, 3 I9, 363, 365, 38I, 399, 4I 8, 453, 6I 7, 623, 656, 769, 796, 845, 853, 865, 907, 952, 964, 980, I004, I024, I033), I 59 (scans 9, 48, I I 5, I 40, I60, I95, 224, 240, 302, 32 I, 354, 39I, 46I, 500, 549, 555, 623, 647, 653, 655, 684, 689, 730, 781 , 798, 835, 858, 860, 889), I60 (scans I 5, 24, 35, 86, I 34, I 43, I69, 265, 296, 3 I 5, 366, 376, 433, 48 I, 504, 538, 558), I6I (scans 20, 32, 4I, I I I, I 24, I 58, I 73, 235 , 255, 279, 3 I8, 397, 4I 3, 4I 5, 456, 484, 506, 523), I64 (scans 44, 46, 56, I IO, I I6, I 37, I 49, I 5 I, I 82, 234, 247, 260, 278, 295, 3 I 3, 333, 399, 4I 6, 480, 486, 5 I I, 529, 549, 594, 6I 5, 642, 664, 702, 776, 84I, 875, 894, 9I 3, 934), I65 (scans I I2, I 70, I80, 2 I 5, 225, 242, 256, 3 I 4, 332, 335, 39I, 399, 492, 507, 559, 574, 582, 609, 627, 656, 693), I66 (scans 8, I09, I 40, I69, 200, 269, 288), I 67 (scans 33, 74, IO6, I I 5, I 3 I, I 58, I 82, 207, 230, 306, 34I, 384, 39I, 402, 428, 472, 486, 563), I 68 (scans 9I, I26, I 50, I65, I77, I 89, 229, 239, 38 I , 4I I , 46I, 474, 52 I, 583, 626, 628, 634, 653, 684, 723, 798, 840, 875), I69 (scans 9, 47, 72, 99, I 47, I 76, I94, 209, 239, 255, 3 I6, 364, 37I , 391, 425, $439,470,5$ I 5, 528, 537, 558, 582, 604, 697, 704, 740, 785, 834, 92 I, 948, 959, 984), I 70 (scans I 9, I 27, 2 I I ) and I 7 I (scans 26, 63, I00, I 86, 225, 245, 283, 300, 335, 38I, 439, 547, 558, 669, 759); 'Value of the guilder' (www.iisg.nl/hpw/calculate.php).

combinations and an expansion of his (lending) business. The latter tallies well with the fact that he started recording serial numbers on each of his IOUs in I 839: an indication that his business administration had indeed grown in the years before and required more careful monitoring.

The I 87 serial numbers available for the period I 839-52 can also be exploited to estimate the annual number of loans provided by Spijker. As the highest serial 
number often dated from November or December, simple extrapolations were used to derive the total number of annual loans. These extrapolations set the serial number on I January at zero and drew a straight line through the latest combination of date and serial number of each year to derive the number of loans on 3 I December of that year. ${ }^{36}$ Figure 3 shows that the number of loans provided annually by Spijker fell substantially during the I 840 s and this helps explain why he was not among the signatories of the 1856 petition that Amsterdam lenders submitted to parliament (see above). As borrowers were primarily seafarers on Dutch ships and as the number of Dutch ships that annually departed from Amsterdam increased (see Section vi), Spijker may have decided autonomously to reduce his lending or he may have been pushed out of the market by competitors.

Whilst the available sources do not make it possible to expand on the latter, they do contain evidence of the former for they suggest that Spijker had gradually specialised in making cigars instead of selling them to seafarers on credit. This helps explain why he sought cigar makers for his factory through advertisements in I859 and I860 and why the address books started referring to him as 'cigar factory owner' (sigarenfabrikant) and 'cigar factory' (sigarenfabriek) rather than merely 'in tobacco'. ${ }^{37}$ Spijker's change of business suggests that the profitability of producing cigars was higher than running his shop and selling to seafarers on credit. As the literature does not typically characterise the profits of shopkeepers and small factory owners as excessive, this forces us to rethink the premiums charged to seafarers (see above). In the literature these premiums have long been interpreted as being exploitative and those who charged them were looked upon with suspicion. The case of Spijker suggests, however, that premiums were high not to take advantage of a group of vulnerable borrowers but rather to cover the high costs and risks of lending to seafarers. Such a revision is even required if Spijker was in fact pushed out of the market by his competitors, because that would point to competitive markets and more agency and a better bottom-line for seafarers. ${ }^{38}$

36 Linear regressions with the serial number as dependent variable, time as independent variable and an intercept that did not necessarily coincide with I January (cf. the simple extrapolations) were also estimated. They yielded slightly higher results in most years, but much higher results in two years because of the particular distribution of the serial numbers available for those years. For reasons of consistency simple extrapolations were therefore preferred. Figure 3 nevertheless slightly underestimates Spijker's lending because new loans were sometimes recorded on the reverse of existing IOUs (i.e. without using a new serial number). As there is no reason to assume that the proportion of loans recorded with(out) new serial numbers changed over time, Figure 3 still provides a good overview of the development of Spijker's lending.

37 Algemeen adresboek der Stad Amsterdam, I859-60, p. 286; I866-7, p. 33 I; I867-8, p. 333; I87I-2, p. 347; Algemeen Handelsblad, 24 February i 859 and 8 October I 860.

38 The Amsterdam lenders, who may of course have been biased, also emphasised this point when they petitioned parliament (see above). See Van Bochove and Van Velzen 2014 for similar conclusions about the premiums charged to employees of the Dutch East India Company. 


\section{I}

Besides shedding light on the business of one specific lender, the Spijker data also make it possible to gauge the overall size and volume of the market for new seafarer loans in Amsterdam during the period I839-52. The annual numbers of loans in Figure 3 were hence related to Spijker's share in each year class of the loans that were still unredeemed in July i 856 . This share dropped in an almost straight line from close to 38 per cent in I 839 to just over I 4 per cent in I 844 and then gradually declined further to just under io per cent in I 852 . As Spijker's share in unredeemed loans must have correlated with his share in newly provided loans, each number of new loans provided by Spijker (as given in Figure 3) was divided by his corresponding share in unredeemed loans to estimate the total number of new loans provided to seafarers by all lenders. To use i 839 as an example, 60 of the I 59 (last repayments on) loans registered in the water bailiff's ledger belonged to Spijker, giving him a share of 37.7 per cent for this particular year. As Figure 3 set the number of new loans provided by Spijker in I 839 at 747 , the number of new loans provided by all lenders was estimated at I,980.

The results are presented in Figure 4 and suggest that the non-bank credit market raised 2,000 to 4,000 new loans for seafarers in Amsterdam each year. The reliability of the estimation procedure is verified by two pieces of information: first, the fact that the estimates tally well with the order of magnitude documented for the number of (last repayments on) loans in I855 (full year) and I856 (incomplete year) in Figure I; second, the fact that the increasing number of new loans closely matched the rising number of Dutch ships that departed from the Amsterdam port. The relationship between the two is logical: seafarers on foreign ships did not require credit since they enjoyed board and lodging on their ships while in Amsterdam, but seafarers on Dutch ships were discharged when they returned to Amsterdam and often depended on credit to bridge the period until their next departure. Collecting repayments from the water bailiff was only possible, moreover, when a ship returned to the Netherlands; something that was much more likely to occur with Dutch than with foreign ships. ${ }^{39}$

With the size of a new loan ranging between 20 and 90 guilders (see above), the size of the credit market for seafarers ranged between 40,000 to 360,000 guilders per

39 Only one other lender - whose IOUs overlapped with those of Spijker - often numbered his IOUs, provided a sufficiently large number of loans and had a market share substantial enough to yield reliable outcomes: J. W. van Recken. During the period I 839-4I Van Recken provided well over one hundred loans annually, which suggests an overall number of new loans of I,I 87 IOUs in I 839, I, 729 in I 840 and I,699 in I 84I. Although these numbers are lower than those of Spijker, they developed similarly and are of the same order of magnitude. This suggests that the procedure applied to Spijker's IOUs provides useful results. As Van Recken's lending dropped substantially in I $842-3$, perhaps because of health issues leading up to his fatal stroke in I843 (see Algemeen Handelsblad, 2 November 1843), estimates of the size of the overall market for these years would be based on shaky foundations and are therefore not included here. 


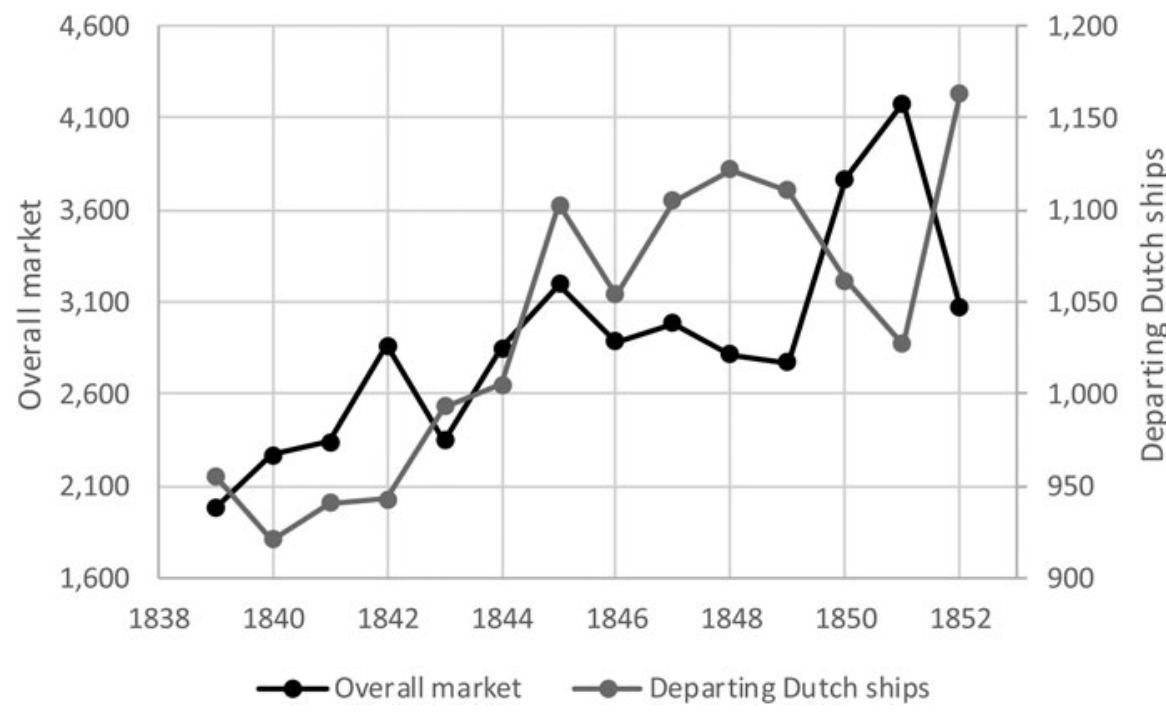

Figure 4. The overall credit market for seafarers (in number of loans) and the number of Dutch ships departing from Amsterdam

Source: Database register waterschout; Figure 3; Van Bochove 20 I4, n. 39; Algemeen Handelsblad, I 3 August I 847 .

annum during the period considered here. ${ }^{40}$ These were quite substantial sums, especially if one realises that the credit market for seafarers was just one niche in the non-bank credit market of a town like Amsterdam. It also raises the question of how such sums were raised by the lenders, especially since money was sometimes fixed for several years. Did they finance their loans themselves or did they rely on outside funding of suppliers or other lenders? The sources in the water bailiffs archive do not shed light on this issue, but it would be worthwhile exploring it in future research.

\section{VII}

Before the rise of banks, people organised credit themselves or with the help of alternative intermediaries. Due to a lack of encompassing sources, however, the size and functioning of these non-bank credit markets have been notoriously difficult to

40 The only useful non-bank credit data to put these figures in perspective are the loans provided by Amsterdam's municipal and licensed pawnshops. Amsterdam City Archive, Archief van de Bank van Leening (entry no. 368), inv. no. I 56 shows that during the period I $839-52$ these institutions annually combined for 0.96 to I.I9 million loans or I.24 to I. 56 million guilders. More pawn credit than seafarer credit was thus provided in Amsterdam, but Amsterdam's population was also much larger than the number of seafarers who annually departed from its port (see note 3 ). As a niche of the non-bank credit market, and especially in monetary terms, the credit market for seafarers was thus relatively substantial. 
analyse systematically. Exceptional sources from the archive of Amsterdam's water bailiff allowed this article to overcome this problem. It could hence determine the size of one particular segment of the non-bank credit market: credit received by seafarers in the decades prior to July i 856 . Seafarers relied on credit to obtain board and lodging, shipping gear and other goods. They secured loans by allowing the water bailiff to make redemption payments from their future wages. An example discussed in this article even showed that a seafarer's wife could obtain credit, while her husband was away, on the basis of his future wages.

Having access to their future wages enabled seafarers in Amsterdam to take out 2,000 to 4,000 new loans each year during the period I 839-52. These loans were relatively small and did not typically seem to have exceeded 90 guilders. Many of these loans were repaid in full, some were partially written off upon a seafarer's death and others were not, or only partially, repaid. These loans, together with similar loans made before I 839 and after I 852 , were registered in the water bailiff's ledger in July I 856 in accordance with the Discipline Act. The ledger registered I 3,708 IOUs presented by 252 lenders and representing about 4I6,000 guilders. The great number of new (I839-52) and (partially) unredeemed IOUs (I856), the substantial sums of money, the large and diverse group of lenders, and the wide use of standardised and pre-printed IOUs suggest that the market for seafarer credit was substantial and well-developed.

Although a core group of shopkeepers and boarding-house keepers dominated lending, lenders from all walks of life felt safe to enter the credit market for seafarers. The water bailiff contributed to this, but relationships between lenders and boardinghouse keepers may also have played a role. Lenders protected themselves for sure by charging double-digit premiums, but this did not imply that profits were excessive. Premiums were relatively high because lenders had to recoup the costs and risks of lending. The example of Cas Spijker suggests that mastering the intricacies of the lending business involved learning: one had to develop an understanding of the sums that one could safely lend to each rank-route combination. The businesses of large lenders like Spijker were complex, based on formal contracts, involved careful recordkeeping and possibly required external funding. This new perspective on these key players in sailor-town suggests that much may be gained by no longer depicting this group negatively as crimps. Approaching them and their businesses more neutrally will undoubtedly improve our understanding of what they were actually doing in a practical and economic sense.

The new insights of this article also raise questions that go beyond the Dutch market for seafarer loans. Did municipal officials like the water bailiff help credit markets in other countries function more smoothly as well? And if the credit market for seafarers was already this big, how much credit did shopkeepers and alternative intermediaries raise in other segments of the non-bank credit market that involved ordinary people and their daily needs? Future research should try to further reconstruct that broad base of the non-bank credit pyramid. 
Submitted: 5 June 2018

Revised version submitted: 3 December 2018

Accepted: 8 January 2019

First published online: 22 April 2019

\section{Sources}

Algemeen adresboek der Stad Amsterdam

Algemeen adres-boek of naamregister van de notabelste inwoners der stad Amsterdam

Algemeen Handelsblad

Amsterdam City Archive, Archief van de Bank van Leening (entry no. 368)

Amsterdam City Archive, Archief van de Waterschout (entry no. 38)

Amsterdam City Archive, Collectie Stadsarchief Amsterdam: Adresboeken (entry no. 30274)

Amsterdam City Archive, Archief van het Bevolkingsregister (entry no. 500o) (https://archief. amsterdam/indexen/bevolkingsregisters_1851-1853/zoek/index.nl.html)

Auswanderer aus dem Großherzogtum Oldenburg, (www.auswanderer-oldenburg.de/getperson.php?person ID $=$ I76758\&tree=Auswanderer)

'Circulaire van den Minister van Justitie van den 3 Isten Mei I 856, no. I20, nopens de rigtige uitvoering der wet, houdende bepalingen omtrent de huishouding en tucht op de koopvaardijschepen' (Bijvoegsel tot het Staatsblad van het Koningrijk der Nederlanden I22)

De Tijd

Dutch National Archive, Archief van de Tweede Kamer der Staten-Generaal, I8I5-I945 (entry no. 2.02.22)

Gepriviligeerd naamregister der heeren kooplieden

Handelingen der Eerste Kamer

Handelingen der Staten-Generaal

Handelingen der Tweede Kamer

His GIS Amsterdam (www.hisgis.nl/hisgis/gewesten/amsterdam/kaart1860/amsterdam1860)

Nieuwe Rotterdamsche Courant

Statistisch Jaarboek der Gemeente Amsterdam nitgegeven door het Bureau van de Statistiek der Gemeente I900 II (Amsterdam, I902)

Utrechtsche Provinciale en Stads-Courant

'Wet van den 7den mei i856, houdende bepalingen omtrent de huishouding en tucht op de koopvaardijschepen' (Staatsblad van het Koningrijk der Nederlanden 32)

WieWasWie (www.wiewaswie.nl/nl/detail/35433099)

\section{References}

AERTS, R. (2006). Het verval, de verkrotting en het verleden. In R. Aerts and P. de Rooij (eds.), Geschiedenis van Amsterdam, vol. III. Amsterdam: SUN.

ALBERT, A. (2012). Working-class consumer credit during the belle époque: invention, innovation, or reconfiguration? Annales: Histoire, Sciences Sociales, 67, pp. 73 I-63.

BIK, E.A. and ROOS, D. (I995). Kromsluiting in de ijzers: Uitspraken van de Raad van Tucht (voor de koopvaardij) 1856-1909. Amsterdam: De Bataafsche Leeuw.

BLAKEMORE, R. J. (20I7). Pieces of eight, pieces of eight: seamen's earnings and the venture economy of early modern seafaring. Economic History Review, 70, pp. I I 53-84.

BOCHOVE, C. VAN (2OI4). Seafarers and shopkeepers: credit in eighteenth-century Amsterdam. Eighteenth-Century Studies, 48, pp. 67-88.

BOCHOVE, C. VAN and KOLE, H. (2OI4). Uncovering private credit markets: Amsterdam, I660-I 809. The Low Countries Journal of Social and Economic History, II, pp. 39-72.

BOCHOVE, C. VAN, VAN LOTTUM, J. and MOURITS, R. (2016). Database Zeelieden en krediet in de negentiende eeuw (https://doi.org/10.17026/dans-27b-t9u2). 
BOCHOVE, C. VAN, MILO, M. and VAN VELZEN, T. (2OI8). Financing employees of the Dutch East India Company through claims on their future salary (working paper).

BOCHOVE, C. VAN and VAN VELZEN, T. (2OI4). Loans to salaried employees: the case of the Dutch East India Company, I602-I 794. European Review of Economic History, I8, pp. I9-38.

BRUIJN, J. R. (I977). Zeevarenden. In F. J. A. Broeze, J. R. Bruijn and F. S. Gaastra (eds.), Maritieme geschiedenis der Nederlanden, vol. III. Bussum: Boer.

BRUIJN, J. R. (1978). Het gelag der zeelieden. Leiden: Universitaire Pers Leiden.

DIXON, C. (1984). The rise and fall of the crimp, I840-19I4. In S. Fisher (ed.), British Shipping and Seamen, 1630-1960: Some Studies. Exeter: University of Exeter.

EASTERLY, M. E. (2008). Your job is your credit: creating a market for loans to salaried employees in New York City, I885-I920. Unpublished dissertation, UCLA.

EASTERLY, M. (2009). Your job is your credit: creating a market for loans to salaried employees in New York City, I885-1920. Enterprise \& Society, I0, pp. 65 I-60.

FINGARD, J. (1978). Masters and friends, crimps and abstainers: agents of control in Igth century sailortown. Acadiensis, 8, pp. 22-46.

FINGARD, J. (I980). 'Those crimps of hell land goblins damned': the image and reality of Quebec's sailortown bosses. In R. Ommer and G. Panting (eds.), Working Men Who Got Wet. St John's: Memorial University of Newfoundland.

FINN, M.C. (2003). The Character of Credit: Personal Debt in English Culture, 1740-1914. Cambridge: Cambridge University Press.

FONTAINE, L. (20I4). The Moral Economy: Poverty, Credit, and Trust in Early Modern Europe. Cambridge: Cambridge University Press.

FURNÉE, J. H. and LESGER, C. (eds.) (20I4). The Landscape of Consumption: Shopping Streets and Cultures in Western Europe, 1600-1900. Basingstoke: Palgrave Macmillan.

GAMBER, W. (2007). The Boardinghouse in Nineteenth-Century America. Baltimore: Johns Hopkins University Press.

GELDERBLOM, O., HUP, M. and JONKER, J. (20I8). Public functions, private markets: credit registration by aldermen and notaries in the Low Countries, I500-I800. In M. Lorenzini, C. Lorandini and D. Coffman (eds.), Financing in Europe: Evolution, Coexistence and Complementarity of Lending Practices from the Middle Ages to Modern Times. Cham: Palgrave Macmillan.

GELPI, R.-M. and JULIEN-LABRUYÈRE, F. (2000). The History of Consumer Credit: Doctrines and Practices. Basingstoke: Macmillan.

HASSELT, W. J. C. VAN (1856). Wet houdende bepalingen omtrent de huishouding en tucht op de koopvaardijschepen. Toegelicht uit de tusschen de regering en de vertegenwoordiging gewisselde stukken, alsmede uit de in de beide kamers der staten-generaal gevoerde beraadslagingen. Ten dienste van HH: reeders, koopvaardij-kapiteins, stuurlieden, enz., enz. Rotterdam: Nijgh.

HELL, M. (20I7). De Amsterdamse herberg: Geestrijk centrum van het openbare leven. Nijmegen: Vantilt.

HOFFMAN, P.T., POSTEL-VINAY, G. and ROSENTHAL, J.-L. (2000). Priceless Markets: The Political Economy of Credit in Paris, 1660-1870. Chicago: University of Chicago Press.

HUGILL, S. (1967). Sailortown. London: Routledge.

JOHNSON, P. (1985). Saving and Spending: The Working-class Economy in Britain 1870-1939. Oxford: Clarendon Press.

JONKER, J. (I996). Merchants, Bankers, Middlemen: The Amsterdam Money Market during the First Half of the 19th Century. Amsterdam: NEHA.

KENT, D. A. (I994). Small businessmen and their credit transactions in early nineteenth-century Britain. Business History, 36, pp. 47-64.

LAFERTÉ, G., AVANZA, M., FONTAINE, M. and PENISSAT, É. (20io). Le crédit direct des commerçants aux consommateurs: Persistance et dépassement dans le textile à Lens (I920-1970). Genèses, 2, pp. 26-47.

LANDHEER, H. (20I3). Een maandceelhouder en zijn klanten: de Amsterdamse logementhouder Hendrik Klaver. Holland, Historisch Tijdschrift, 45, pp. I $37-45$.

LEEUW, C. M. VAN DER (I857). Over de tucht op de koopvaardijschepen. Leiden: Jacs. Hazenberg, Corns. Zoon.

LEEUWEN, M. H. D. VAN and OEPPEN, J. E. (I993). Reconstructing the demographic regime of Amsterdam I68I-I920. Economic and Social History in the Netherlands, 5, pp. 6I-IO2. 
LESGER, C. (2013). Het winkellandschap van Amsterdam: stedelijke structuur en winkelbedriff in de vroegmoderne en moderne tijd, 1550-200o. Hilversum: Verloren.

LEVY, J. (2OI2). The Making of a Market: Credit, Henequen, and Notaries in Yucatán, 1850-1900. University Park, PA: Pennsylvania State University Press.

LLUCH, A. (20I6). The art of lending in the Pampas: commercial credit and financial intermediation in Argentina, I900-I930. In B. Bátiz-Lazo and L. Efthymiou (eds.), The Book of Payments: Historical and Contemporary Views on the Cashless Society. London: Palgrave Macmillan.

LOGEMANN, J. (ed.) (20I2). The Development of Consumer Credit in Global Perspective: Business, Regulation, and Culture. New York: Palgrave Macmillan.

LOGEMANN, J. and SPIEKERMANN, U. (20I0). The myth of a bygone cash economy: consumer lending in Germany from the nineteenth century to the mid-twentieth century. Entreprises et histoire, 2, pp. I2-27.

LORENZINI, M. (20 I 8). Borrowing and lending money in Alpine areas during the eighteenth century: Trento and Rovereto compared. In M. Lorenzini, C. Lorandini and D. Coffman (eds.), Financing in Europe: Evolution, Coexistence and Complementarity of Lending Practices from the Middle Ages to Modern Times. Cham: Palgrave Macmillan.

LOTTUM, J. VAN (2007). Across the North Sea: The impact of the Dutch Republic on International Labour Migration, c.1550-1850. Amsterdam: Aksant.

MILne, G. J. (2016). Sailortown: People, Place and Power on the Nineteenth-Century Waterfront. Cham: Palgrave Macmillan.

MORRIS, D. and COZENS, K. (20I7). Mariners ashore in the eighteenth century: the role of boarding-house keepers and victuallers. The Mariner's Mirror, I03, pp. 43 I-49.

MULDREW, C. (I998). The Economy of Obligation: The Culture of Credit and Social Relations in Early Modern England. Basingstoke: Macmillan.

O'CONNELL, S. (2009). Credit and Community: Working-Class Debt in the UK since 1880. Oxford: Oxford University Press.

OGILVIE, S., KÜKPKER, M. and MAEGRAITH, J. (20I2). Household debt in early modern Germany. Evidence from personal inventories. Journal of Economic History, 72, pp. I34-I67.

OLNEY, M. L. (I99I). Buy Now, Pay Later: Advertising, Credit, and Consumer Durables in the 1920s. Chapel Hill: University of North Carolina Press.

OLNEY, M. L. (I998). When your word is not enough: race, collateral, and household credit. Journal of Economic History, 58, pp. 408-3 I.

ROSSUM, M. van (2008). 'Goed scheepsvolk nodig?' Logementhouders en arbeidsmigranten in Rotterdam, I9I5-I925. Holland, Historisch Tijdschrift, 40, pp. I8-38.

SCHUMAN, P. (I995). Tussen vlag en voorschip: een eeuw wettelijke en maatschappelijke emancipatie van zeevarenden ter Nederlandse koopvaardij 1838-1940. Amsterdam: De Bataafsche Leeuw.

WAGENINGEN, E. VAN (2002). Geldersekade: tussen wag en schreierstoren. Amsterdam: Stadsherstel Amsterdam.

WILLEMS, B. (2009). Leven op de pof: krediet bij de Antwerpse middenstand in de achttiende eeuw. Amsterdam: Aksant. 